\title{
Disconnected Precordial Electrode V4 by ECG Finding
}

National Cancer Institute

\section{Source}

National Cancer Institute. Disconnected Precordial Electrode V4 by ECG Finding. NCI Thesaurus. Code C114156.

An electrocardiographic recording in which the electrode for lead V4 is disconnected resulting in missing waveforms (flat line) for lead V4. (CDISC) 